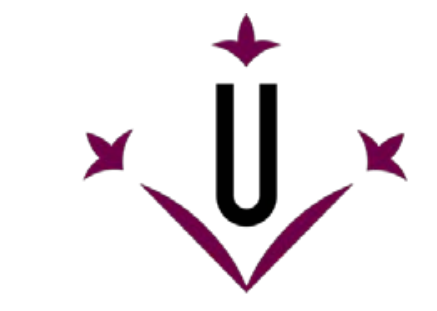

Universitat de Lleida

Document downloaded from:

http://hdl.handle.net/10459.1/67707

The final publication is available at:

https://doi.org/10.1080/07908318.2016.1153108

Copyright

(c) Taylor \& Francis, 2016 


\section{The Englishisation of higher education in Catalonia: A critical sociolinguistic ethnographic approach to the students' perspectives ${ }^{1}$}

Author's name and surnames

Affiliation

This paper investigates the attitudes towards Englishisation displayed by 30 students enrolled in a Combined Languages degree, including English and another language, in a top-ranked university in Catalonia, where a majority language, Spanish, coexists with a minority language, Catalan, and where foreign language teaching is relatively new. Through observational data collected over a two-year fieldwork project, I describe how this institution implemented this partial English-medium instruction program for the first time in Spain, as part of its internationalisation mission. I then focus on the students' perspectives towards the officialisation of English as the third language of the Catalan tertiary education system. I analyse 30 argumentative essay assignments which show that students mobilise both favourable and unfavourable discourses on this language. They envision English as an asset for employability and educational excellence, and as a post-national 'democratic' code for intercultural communication. However, they also construct it as a politicised language which threatens linguistic diversity. I conclude that these conflicting attitudes respond to the particular sociolinguistic configuration of globalised universities in Barcelona. This contributes to a more nuanced understanding of the students' range of situated stances concerning the linguistic regimes that govern the European multilingual policies of higher education, in late capitalism.

Keywords: bilingual higher education; internationalisation; Englishisation; student attitudes; Catalonia 


\section{Introduction: The Englishisation of the Catalan university system}

Catalonia is a bilingual autonomous community of 7,518,903 inhabitants (Idescat, 2014) in Spain where a majority nation-state language, Spanish, coexists with a minority national language, Catalan, which has over ten million speakers in Europe (Pons Parera, 2015, p. 153). Its tertiary educational system, with a body of 219,219 students (Idescat, 2013a), has gone global over the past few decades. In 1999, all Catalan public universities $^{2}$ joined the European Higher Education Area (EHEA), thereby investing in the internationalisation process that characterises the socio-economic restructuring of European universities in the $21^{\text {st }}$ century (Cots, Llurda, Armengol, \& Arnó, 2013; Cots, Llurda, \& Garrett, 2014; Llurda, Cots, \& Armengol, 2014; Vila, 2015). The aim of this internationalisation mission was to standardise the teaching, research and service functions of Catalan higher education institutions with those of Europe, so as to (1) compete in the international profit-making educational marketplace; (2) attain higher educational standing and prestige worldwide; and (3) promote mobility, cross-border collaborative work and partnership agreements among diverse academic and administrative staff, and students (Garrett \& Gallego Balsà, 2014, p. 361).

The first internationalisation policies of the European Union addressed the increased linguistic diversity of those countries who had signed the Bologna Declaration by establishing newer language directives which fostered the inclusion of all languages into their university curriculums (i.e. majority, minority, regional and migrant languages). These multilingual programs were also designed to foster 'democratic harmony' (Del Valle, 2006, p. 32) and to promote civic European citizenship values among all university stakeholders (Huguet \& Lasagabaster, 2007, p. 235). On the ground, though, these internationalisation plans basically set the basis for the officialisation of English as the lingua franca of the European tertiary education institutions (Llurda, Doiz, \& Sierra, In Press), and, more generally, as the most widely spoken foreign language throughout Europe (Eurobarometer, 2006, p. 12).

In the Catalan bilingual context, where the introduction of English at university had a much shorter tradition than in other parts of Europe (Lasagabaster, Cots, \& Mancho-Barés, 2013, p. 756), the management of linguistic diversity materialised in different language policies based on 'trilingualism' (Garrett, Cots, Lasagabaster, \& Llurda, 2012, p. 141), which established that all students should be fully competent in the two co-official (Romance) languages of the region and, then, at a later stage, in English, upon completion of their degree (DOGC, 2003, p. 3329). ${ }^{3}$ 
These policy plans were, in part, instigated by the Catalan Government, a key promoter of 'Europeanisation' ('europeïtzació') (DOGC, 2003, p. 3327). The Catalan governmental authorities started to fund those universities that implemented trilingual language policy actions ensuring both the protection and promotion of Catalan and the use of English as the third instructional lingua franca of these academic communities (Pons Parera, 2015). This language intervention strategy aimed at balancing the introduction of English into the Catalan educational system with the monitoring of the institutional roles attributed to the two official local languages in Catalan universities (Bastardas, 2003, p. 8; Lasabagaster et al., 2013, p. 755), in a complex context where Catalan, not recognised as an official language by the European Union, is still emerging from a long trajectory of subordination (see Pujolar, 2001), and where Spanish has a dominant position as the official language of the entire Spanish nation-state - and as a powerful lingua franca worldwide (Del Valle, 2006).

Englishisation at the UAB: The case of the new Combined Languages Degrees in English

Today, all Catalan universities have a specific language strategy commissioned by their respective Governing Councils which spells out the different ways in which the threelanguage plan is to be gradually deployed in each of these institutions (see OPUC, 2015). The Autonomous University of Barcelona (UAB) provides a particularly illuminating example of the ways in which large universities located near cosmopolitan global cities like Barcelona started investing in trilingualism, and of how they did so basically by officialising English as their lingua franca, as detailed below.

Occupying the $166^{\text {th }}$ position in the world's top-ranked higher education institutions and the $2^{\text {nd }}$ position in Spain (SIR WR, SCImago, 2014), the UAB is a university community of approximately 40,000 members, divided as follows: 28,012 undergraduates (with 5.1\% international students); 1,940 MA and 4,015 $\mathrm{PhD}$ students (with 36.4\% foreign students); 3,571 academic staff (with 4.54\% international researchers and visiting professors); and 2,425 administrative staff (UAB Àrea de Comunicació i Promoció, 2015a).

Following the classic rhetoric of advanced liberal democracies which mobilises institutional discourses on inclusiveness and which fosters 'unity in diversity' (Heller, 2006 [1999]), the UAB presents itself as a 'multicultural community' offering 'a 
welcome in any language' (UAB Àrea de Comunicació i Promoció, 2014). However, it systematically conflates the management of linguistic diversity with Englishisation; that is, with the establishment of English as the official foreign language of the university, and with the implementation of English-medium instruction (EMI) courses in the classroom (see, e.g., Kirkpatrick, 2011, p. 2; Phillipson, 2009, p. 37), as exemplified in its current Plan for Languages.

Valid from January 2011 to December 2015, monitored by the Language Policy Committee, and delegated by the Governing Council of this university, the UAB Plan for Languages is presented as 'a model of governance for multilingualism in universities'. It defines Catalan as 'the autochthonous language of the UAB', and Spanish, as 'an official language [...] important for the University's internationalisation strategy' (UAB Governing Council, 2011a, p. 2). It then recognises 'plurilingualism' as 'a strategic asset for internationalisation' (UAB Governing Council, 2011a, pp. 3-4), and, finally, it presents English as the third language of the UAB (Estella, 2013, p. 45), ${ }^{4}$ as illustrated in the extract below, reproduced verbatim:

\begin{abstract}
English has become the lingua franca of the international academic community and is essential for attracting and retaining talent, achieving the University's objectives of internationalisation and excellence. [...] It is increasingly used as a working language in the University's activities and is an active key to the academic development of our students. This means that is it [sic] necessary to formalise the status of English as the lingua franca while differentiating English from the other non-official languages, in accordance with the delivery of classes in English in undergraduate and postgraduate courses. (UAB Governing Council, 2011a: 2-3, author's emphasis)
\end{abstract}

The four official Combined Languages Degrees in English (henceforth CLDsE) were part and parcel of this plan, and epitomise the UAB's active investment in the progressive implementation of new partial English-medium instruction degrees at the Faculty of Letters. ${ }^{5}$ Presented as 'the most multilingual, new and unique educational offer in the entire Spanish state' which equips students with 'expert knowledge' and 'solid training' for the language-based tertiary career options of the global marketplace (UAB Àrea de Comunicació i Promoció, 2012), the CLDsE depend on the academic and administrative resources of the five Language Departments at the UAB (i.e., on the joint collaboration of the English, French, Catalan, Spanish and Classics Departments). In terms of curriculum, they offer partial EMI courses on the language, literature, 
culture and history of English, and on the language, literature, culture and history of any one of the other four languages. That is, almost half of the subjects (105 ECTS) are taught integrally in English, and the rest (105 ECTS), in French, Catalan, or Spanish (Classics include Latin and Greek, too), with a choice of a 30-ECTS-credit module in yet a third language (German, French, Italian, Galician, or Basque). The two-fold aim of these CLDsE, therefore, is to provide linguistics and literature content (e.g. 'Language Acquisition' or 'Victorian Literature') and to teach these subject matters in a heteroglossic bi-/multilingual manner, ensuring, in turn, that students will attain a $\mathrm{C} 2$ level of English (of the Common European Framework of Reference for Languages), upon completion of the degree.

During the academic year in which they were first offered (2009-2010), the CLDsE registered 40 students. In 2014, the number of first- to fourth-year CLDsE students had risen to 327 ; about $80 \%$ of whom were Catalan young women aged 20-21, in average (for more details, see Tables 1 and 2 in the Appendix) - this gender imbalance in language-related degrees has been attested in many other Catalan universities (see, e.g., Llurda, et al., In Press). This was the highest number of enrolments in the entire Faculty, ${ }^{6}$ which is indicative of the success of these new Englishisation initiatives. It is precisely the experiences and perceptions of the third promotion of students who decided to participate, first-hand, in the design and implementation of these CLDsE who are the object of this study, as detailed in the following section.

\section{The study: A critical sociolinguistic approach to the Catalan students' views on English and on Englishisation}

The language policy strategies described above allow us to investigate the ways in which traditionally bilingual higher education systems in Europe transformed into truly transnational enterprises, under the umbrella of the EHEA (Garrett et al., 2012, p. 140). This is so for two main reasons. On the one hand, the tracking down of these language plans, institutionalised in a top-down fashion, provides privileged access to the logics behind the different roles that the English language has played, and plays, in nonEnglish-speaking regions like Catalonia (Cots et al., 2014, p. 312). On the other hand, the historicising of these trilingual policy actions may allow for a context-grounded analysis of the 'attitudes' (Sabaté i Dalmau, 2014, p. 176) or stances with which all faculty members, from their different situated positions, assess language intervention, 
conditioning their success (or failure) in a bottom-up manner (Huguet \& Lasagabaster, 2007, p. 246). This is a research arena for which we also need more local micro-level case studies (Llurda et al., In Press).

In this article, I try to contribute to these two intertwined lines of research by adding an informant-oriented, critical sociolinguistic ethnographic perspective (Duchêne, Moyer, \& Roberts, 2013) to the multidisciplinary work that has been conducted on the attitudes on English as a lingua franca mobilised by students in different Catalan university settings (see, e.g., Cots et al., 2013; Cots et al., 2014; Garrett \& Gallego Balsà, 2014; Garrett et al., 2012; Huguet, 2007; Llurda et al., In Press; Rosselló i Peralta \& Boix-Fuster, 2006). In particular, I try to explore the frequently ambivalent or conflicting views of CLDsE students on English and on Englishisation policies and practices at the UAB by addressing the following research questions:

1. What are the attitudes of Catalan university students majoring in a CLDsE towards the roles of English in the Catalan tertiary education system? What beliefs concerning the establishment of English as the university lingua franca do they mobilise, as social actors who chose to devote their academic and work prospects to the mastering of this language? And what is the rationale behind these views?

2. What reported facts and perspectives concerning recent Englishisation initiatives emerge from these future language experts, who experienced, first-hand, the design, piloting, and implementation of new partial EMI degrees such as the CLDsE?

3. How does the traditionally bilingual sociolinguistic context of the university under study shape the students' take on the English language? That is, how do their lived experiences with regard to their majority and minority languages interplay with their views on English? And to what extent can the particular geo-demographic profile of this student body account for these views?

4. Finally, more generally, what can their attitudes towards English tell us about the place that this language occupies in the broader stratifying linguistic hierarchies which govern the neoliberal multilingual language policies of European universities in which all Catalan students are now fully immersed?

The data gathered in order to answer these questions come from multiple sources, including: 
1. The researcher's involvement in the third-year implementation of the CLDsE, in coordination with the UAB Faculty Board, as the academic coordinator of these majors (September 2012-November 2013). This experience provided access to: (1) the internal documents concerning curriculum design, assessment system, timetables, and specific mobility programs; (2) the reports gathering student profiles; and (3) the first-to-fourth-year students' input on the CLDsE (suggestions, complaints, and so on), provided in group discussion sessions and in regular meetings with the CLDsE Student Delegation, the official organ of the student body operating in coordination with the Academic Affairs Committee. ${ }^{7}$

2. The researcher's participant observation, and shadowing, of 194 CLDSE students in the English classroom (September 2011-November 2013), as one of the two English instructors of their compulsory C1- and C2-level courses 'Use of English 1' and 'Use of English 2', undertaken, respectively, during their second and third academic years (this included three individual follow-up tutorial sessions with students).

3. 30 argumentative essays written by students on the topic of English as a lingua franca. These were provided by one of the two groups of all second-year CLDsE students (on October 16, 2013), as part of a written assessment which accounted for $5 \%$ of their final mark in the 'Use of English 1' course. This group consisted of 33 students (notably, 29 females and 4 males), aged 20 years and 4 month (in average), who were studying the following combinations of languages: English and French (11 students); English and Catalan (9); English and Spanish (5); and English and Classics (4) - the four remaining students were 3 Erasmus female students from Lithuania who enrolled in the English-Spanish program, and a Catalan male student majoring in Economics who undertook the course as part of his 30-credit Minor in Professional English (the Erasmus discourses have obviously been acknowledged in the analysis section). The geo-demographic profile of this class was as follows: there was a notable group of 6 Catalan-dominant students who had moved from the Balearic Islands in order to major in a CLDsE; 4 Spanish-dominant students who, for the same reason, had come from other parts of Spain where some Catalan is also spoken (basically, Aragó, València and Alacant); and 4 Catalan-dominant students who were raised in diverse Catalan-speaking regions situated an hour, at least, from Barcelona City (e.g. Guissona, Cardedeu, Palafrugell, Girona). The rest of students (apart from the Erasmus) were from post-industrial medium-sized towns located in 
the metropolitan area of Barcelona (Barcelona City, Sabadell, Rubí, Molins de Rei and Sant Boi de Llobregat).

The individual essay-writing task that these students were assigned was conducted at home after having read a newspaper article entitled 'English language debate renews questions' (Geller, 2006), and after having done a series of vocabulary, reading and speaking activities in class. The unit as a whole was designed to enhance critical thinking and socially-engaged reflection around the local and global roles of English. However, the particular writing task was not restricted to this aim, as I wanted students to discuss these roles from their own situated perspective; that is, in connection to their 'here-and-now'. For this reason, I also employed other discourse elicitation devices broadly connecting language to economy, employment and migration issues, and waited to detect what particular interests or topics of concern the article had raised among them. The following list of prompts was provided: 'The role of English as a lingua franca'; 'Current English language debates'; 'The need for the officiality of languages'; 'English and job opportunities/careers'; 'University life and employability'; and 'Language and im/emigration from and to Catalonia'.

The analysis was conducted by first dividing the essays into the thematic areas provided in the list of prompts. Then, all discourse markers in (1) the titles; (2) the thesis statements in the introductory paragraphs; (3) the topic (and sub-topic) sentences of their arguments, counterarguments and refutations in the main body of the texts (exemplified by means of presenting case studies and factual information); and (4) the closing statements in the concluding paragraphs were examined in detail and divided according to whether they connoted explicit (a) favourable; (b) unfavourable; (c) favourable and unfavourable; (d) or neither favourable nor unfavourable attitudes towards linguistic diversity; that is, towards English, Catalan and/or Spanish, or any other language. 10 essays which were illustrative of the main findings that emerged after the analysis were selected. These are presented, verbatim, in the form of 16 excerpts, in the section below. Needless to say, these data were gathered with oral and written informed consent. All names used are pseudonyms in order to preserve the anonymity of the informants, following the guidelines for academic research established by the UAB Ethics Committee. 


\section{Findings: Ambivalence, contradiction and ideological tension framed within a neoliberal regime of thought}

With revealing essay titles such as 'One language unites the world' or 'Hostile languages', the CLDsE students' essays disclosed a series of attitudes towards the local and the global statuses of English which at times were contradictory. These are discussed under the umbrella of three positive and two negative perspectives on this language.

\section{Positive attitudes}

English as a pragmatic economic asset for employability

The vast majority of students envisioned the English language as a key 'asset' for future employability, and understood their investment in it as a way to ensure some socioeconomic upward mobility, upon completion of their degree. This was the attitude that was most frequently mobilised among students (also during our class discussion sessions), given that the task was assigned in the context of the current economic recession in Catalonia (note that the unemployment rate among people aged 16-29 was $32.2 \%$ in 2014; Observatori Català de la Joventut, 2015, p. 11). This is illustrated in Rosa's essay (Excerpt 1), entitled 'Looking for a dream abroad' (sentences or phrases removed for space constraints are indicated with $[\ldots])$.

1. This generation is having to fend for itself like never before. The current economic situation in Spain and other countries is developing an environment of uncertainty. Students, graduates and young people [...] have no expectations about their professions, what is producing a general demoralization. [...] we have to abandon our lands because here there is no future. (Rosa, female, 20, Alacant, BA in English-Spanish)

As can be observed, these work prospects were projected upon the international scene, for students stated that a proficient command of a foreign language (basically English) was a 'must' for accessing both the local and the global marketplace, when trying to find employment. This is illustrated by Mariona in an essay entitled 'Magic experience of going abroad' (Excerpt 2); by Aina in her composition 'Running away 
from Spanish reality' (Excerpt 3); and, finally, by Paula, in her essay 'English at school' (Excerpt 4).

2. You also have to learn a new language and it will make your curriculum better. Furthermore [...] present day employers give a huge importance to having had a job in a foreign country. (Mariona, female, 20, Balearic Islands, BA in English-Catalan)

3. Everybody wants to contract someone with experience abroad and the competence to speak more than one language. (Aina, female, 20, Balearic Islands, BA in English-Catalan)

4. Having a good command of English equals more job opportunities and the possibility of working in any country of the world. (Paula, female, 20, Barcelona, BA in English-Catalan)

In these excerpts, students construct multilingual competence (including an effective command of English) as a pragmatic worktool; that is, as a form of capital which enhances their employability chances and opens the doors for them to become part of the European workforce (I follow Bourdieu's notion of capital and of resource; see Bourdieu, 1977, 1986). Access to this utilitarian 'global commodity' (Pennycook, 1994, p. 145) is uncritically presented as a socio-professional necessity, rather than as a matter of wish or personal choice (note the use of the modality verb of obligation 'have to' in the statement 'you have to learn a new language', by Mariona).

The view that a credentialed proficient level of English provides better future work prospects, which is also shared among pre-university Catalan high school students (Flors, 2013, p. 205) and among college undergraduates in other Catalan university settings (Garrett \& Gallego Balsà, 2014, p. 368; Lasagabaster et al., 2013, p. 765; Rosselló i Peralta \& Boix-Fuster, 2003, p. 4), follows a neoliberal regime of thought in two regards. On the one hand, it is framed within a discourse of 'linguistic instrumentalism' (Wee, 2008, p. 32), where language is seen as a consumer item; that is, as a profitable 'added-value' technical asset devoid of social, cultural or political meanings and of identity connotations (Heller \& Duchêne, 2012). On the other hand, it also supports the 'pro-multiculturality' civic rhetoric that values an inclusive, postnational 'linguistic diversity' which, in reality, is abstractly or very loosely defined (Krzyzanowski \& Wodak, 2011, p. 126). 


\section{English as the cultural capital for educational prestige}

In a similar vein, many students also constructed the English language as an educational resource embodying the sort of cultural capital which provides them with academic distinction and prestige. English is associated with 'high culture' in Catalonia because its widespread learning and teaching has been scant until recently (Llurda et al., In Press), despite the fact that it is the first most spoken foreign language in this region (Idescat, 2013b). This is illustrated by Paula (Excerpt 5), who was extremely critical about the Catalan bilingual educational system, concerning the treatment of foreign languages in the curriculum which, she considered, did not prepare future generation for internationalisation.

5. English is the most spoken language on earth. In the majority of countries all over the world it's as important as the official language, so children learn it from a very young age in the same measure as their mother tongue. This is not the case of Spain, though. English is considered a secondary language. [...] Spain is one of the countries with the lowest English level in Europe, if not the worst. Proof of that are, for example, the politicians, who speak with bad grammar and worse pronunciation. [...] English should be given the same importance as the mother tongue at school, so next generations will be more prepared to this globalized world we live in. (Paula, female, 20, Barcelona, BA in English-Catalan)

Students also presented English as one of the most helpful languages in their daily academic activities, particularly when trying to gain access to up-to-date information and knowledge. This is illustrated by Judit (Excerpt 6), in her essay 'English, the universal language' (note, again, the use of the modality verb of obligation 'must' in the statement 'anyone [...] must understand English', which presents a proficient command of English as a requirement):

6. Most websites are written in English. Anyone who wants to find the best information online must understand English. Likewise, if one wants an 
article to reach the largest number of people possible, writing in English is a safe bet. (Judit, female, 20, Barcelona, BA in English and French)

What is also relevant about the discourses that allude to the use of foreign languages at university is that they unravel the fact that CLDsE students share a strongly prescriptivist, monoglossic view of language. That is, they foster the teaching and learning of 'pure' English forms in a native-like manner, to the extent that on some occasions they even delegitimise and censor their own effective command of it, as nonnative speakers. This is illustrated by Marta (Excerpt 7) who, in her essay 'Shut up better than use the language', complains about the 'negative interference' of Spanish with her English language learning process (note, also, Paula's general criticism of translinguistic English communicative practices in Spain, which she classifies as 'bad grammar' and 'worse pronunciation', in Excerpt 6):

7. Learning new languages $[\ldots]$ we confused their rules with our mother tongue and we make grammar mistakes. (Marta, female, 21, Uruguay, bilingually schooled and raised in Barcelona, BA in English-Spanish)

Further evidence that CLDsE students target a command of English hegemonic standard norms was provided in one of the first meetings that we held with all first- to fourth-year students, which aimed at organising the CLDsE Student Delegation and at listing the general concerns that students shared with regard to the implementation of these majors. Students not only agreed with the level expectations required in the three instrumental English language courses that they had (which included B2-, C1- and C2level exams over three years) but also demanded the use of similar language tests in the other foreign languages that they were also studying (namely in French). In the first written reports that they passed onto the CLDsE academic coordinator (i.e. the researcher) and onto the Academic Affairs Committee, for instance, they wrote: 'During the first year of English, they [instructors] harp on and on about [the B2-level course] "Basic English Uses", as it should be with the rest of all the other courses' (internal report written on Google Docs via Facebook; February 26, 2014; author's translation). ${ }^{8}$

One would perhaps expect these students to share some negative feelings towards foreign language testing, given that it did not work to their advantage. The number of students failing the first- and the second-year courses on instrumental 
English was problematically high, to the point that the Faculty of Letters had to offer a third parallel course for repeaters. $21.2 \%$ of students in the group under study were repeating the $\mathrm{C} 1$-level course and had already taken the previous B2-level course twice. This means that, in reality, they had to invest four years of effort, time and money to obtain the $\mathrm{C} 1$ English certificate. And yet, they kept demanding the institutional credentialing of their effective English language command.

Thus, contrary to what has been found in other contexts where students had not chosen to gear their professional prospects towards attaining expertise in the English language realm (Cots, 2013, p. 114; Rosselló i Peralta i Boix-Fuster, 2003, p. 5; Llurda et al., In Press), the CLDsE students' lack of proficiency does not translate into negative stances towards the implementation of Englishisation policies and practices. In fact, the opposite is true: lack of foreign language command, in this case, seems to motivate students to work hard in order to obtain the certificates which in theory should provide them with the high-standards multilingual curriculums and distinctive employability profiles.

\section{English as a necessary tool for intercultural communication}

The two intertwined discursive tropes presented so far are also explained by the fact that English seems to index an emotionally 'neutral' language in the Catalan university context (Huguet, 2007, p. 32; Llurda, 2009, p. 125); that is, a language which is 'external' to the politicised sociolinguistic workings of Catalan society. In this sense, it is envisaged as an instrumental tool for establishing successful 'intercultural communication' (Piller, 2011, p. 5). Following this stance, some CLDsE argue for what in effect is an 'economisation of linguistic diversity' (Duchêne, 2011, p. 102) and foster a pragmatic hierarchisation (or prioritisation) of a few dominant lingua francas in order to make global communication feasible, with English playing a dominant role. In Excerpt 8, Marta defends the use of English (which she had previously mentioned in her essay) as the single official world language, apparently suggesting that multilingualism is a hindrance or impediment for global unity.

8. There are more than 3.000 languages coexisting. As a result, one of the drawbacks of the globalization is the lack of a single official language worldwide. [...] The existence of many languages is a major impediment for 
foreigners who want to move to a new country. (Marta, female, 21, born in Uruguay, bilingually schooled in Barcelona, BA in English-Spanish)

Another group of students, by contrast, show unfavourable attitudes towards this 'economisation' and argue for an understanding of linguistic diversity as encompassing not only English but also other minority, regional and majority languages (similar results were reported in Garrett et al., 2012, p. 153; Llurda et al., In Press; Lasagabaster et al., 2013, p. 757). This is illustrated by Laura (Excerpt 9), who in her essay 'Language beyond boundaries', states that limiting the choices of foreign languages to English only is counterproductive for the defence of values linked to citizenship rights, such as tolerance, inclusion and democracy, presented as the 'central values of civilisation' (Harvey, 2005, p. 5).

9. This knowledge in more than just two or three languages makes little by little the boundaries disappear that we put to ourselves and make the world a little bit more united. It seems that some kind of fear to get closer to other cultures exists and people resign themselves to know just their current language and English. (Laura, female, 20, València, BA in English and French)

Interestingly, this tendency to associate intercultural communication necessarily in and through foreign languages other than English is basically shared by those CLDsE students who came from the Balearic Islands. Most of them had chosen the 30-ECTS German module, which will allow them to have a BA diploma officially certifying the effective command of at least English and German. This may well respond to the particular work prospects of this (sub)-group of students, who projects their wished-for professional trajectories back in the Islands, where the tourism industry seems to be crisis-resistant (Exceltur, 2013); and where the biggest group of foreign residents is the German community (Sastre Bestard, 2013, p. 229). This may explain why CLDsE students from Barcelona (like Paula and Judit) tend to speak about 'English', whereas students from the Balearic Islands (like Mariona and Aina) tend to mention 'new' or 'foreign languages' when addressing linguistic diversity.

\section{Negative attitudes}


Generally speaking, the newspaper article provided for the essay-writing assignment triggered more positive than negative views concerning English and Englishisation. Unfavourable attitudes, though, were much more emphatically stated, and basically revolved around the negative social consequences derived from the overarching weight and power that this language has been granted over the past few years in the global scene, as explained below.

\section{English as a reproducer of social inequality and linguistic marginalisation}

A few students mobilised very negative attitudes towards English. Those who did so basically stressed the political interests behind the attempts at establishing it as the only global lingua franca, following the oft-quoted work of the researchers that they had chosen to read for the task (e.g. Phillipson, 1992). More specifically, they envisioned English as a post-colonial reproducer of socio-economic ethnoracial difference, inequality and exclusion among non-English dominant populations inhabiting Englishspeaking world regions - in particular, the United States. Besides, they called those who fostered the officialisation of English in that part of the world 'narrow-minded conservatives', 'fundamentalists', 'prejudiced' and 'xenophobic'. This is exemplified by Oriol (Excerpt 10), who, in his essay 'English language debate in the USA: A misguided approach', employed the social identity labels that I have just mentioned, denounced linguistic marginalisation in the North American context, and stated:

10. Claiming that English needs to be officialized is baffling, to say the least. [...] Some experts on the subject have even gone as far as claiming that the expansion of English is a case of 'linguistic imperialism'. (Oriol, male, 20, Girona, BA in English-Catalan)

Curiously enough, in the discourses that display strong criticism around English in the international arena (similarly found in Rosselló i Peralta \& Boix-Fuster, 2006), no negative comments were found on the business that lies behind the EFL industry, in the form of multinational corporations selling materials, credentialing levels or setting up language schools (as attested in Pennycook, 1994, p. 158, 2009, p. 209), in a system which has 'mercantilised' the teaching of multilingual competence in the EHEA (Fairclough, 2006, p. 73). There was no mention, either, to the market-driven 
governmental strategies of advanced liberal democracies like Catalonia who, in parallel, have also started to foster an understanding of university education as a new form of 'entrepreneurialism', and who, therefore, address the student body in clienthood terms (Deem, 2001, pp. 9-10).

It is relevant to highlight, though, that there were some dissenting voices who very critically wrote about the sharp increase in tuition fees, which was associated with the 'Europeanisation' of Catalan universities (the overall price of a degree within the disciplines of Humanities increased by $172.25 \%$ between 2007-2008 and 2013-2014; OSU, 2013, p. 13). This is illustrated by Blanca (Excerpt 11) who, in her essay 'Education: something disappearing', complains that:

11. The government should be more interested in education as it seems nowadays and stop reducing the budget of it. Those kinds of things are making this country to seem less developed as it is. (Blanca, female, 20, Barcelona, BA in English-Spanish)

At least two of the CLDsE students who participated in this study were affiliated to, and conducted social activism within, a Catalan students' communist union. Throughout the course, they invited their classmates to anti-privatisation strikes, and they posted massive pieces of information concerning the demise of the public university system via social media communication (in the Student Delegation's Facebook). This information concerned the negative socio-economic and educational consequences of the local deployment of the Bologna Plan and, therefore, crucially addressed the problems of internationalisation for Humanities and Social Sciences degrees in Catalonia. However, students left the parallel process of Englishisation unmentioned - as if, for them, the implementation of trilingualism was detached from the internationalisation strategies of the EHEA. ${ }^{9}$

\section{English as a post-colonial challenger for minority languages}

Only a few students explicitly wrote against the officialisation of lingua francas such as English, but several, by contrast, wrote in favour of providing institutional protection and continued recognition to minority languages. Oriol, for instance, was in favour of 
officialising 'subsidiary' languages, presenting the historical trajectory of the Catalan language as a case in point, in Excerpt 12.

12. Giving legal status to second languages usually prevents them from being relegated to oral and informal contexts. [...]Catalan [...] would be extinct if it hadn't been standardized. (Oriol, male, 20, Girona, BA in English-Catalan)

The CLDsE students who mobilise similar discourses believe that giving English a prominent status quo in society is incongruous with protecting and promoting a minority language. As has been attested among some students in other Catalan universities (Garrett \& Gallego Balsà, 2014), there were a few CLDsE students in class who adopted a defensive 'bunker attitude' (Baker, 1992, p. 136) towards English, conceiving of it as a 'predator language' (Cots, 2013, p. 112); that is, as a challenge for the normalised vitality of minority languages. This is exemplified by Laura (Excerpt 13), who generally talks about 'language loss', and by Judit (Excerpt 14), who calls English a 'threat' endangering the 'purity' of other (unnamed) languages, once again exposing prescriptivist monoglossic views on linguistic codes.

13. It looks like you can go wherever you want just knowing English, which means an impoverishment of the cultures and a gradual disappearance of minor languages. (Laura, female, 20, València, BA in English-French)

14. English has spread immensely all around the world ... It has influenced other languages and it has become the main language of international communication ... This dominance is endangering the rest of languages or, at least, their purity ... English ... is a threat for the rest of them. (Judit, female, 20, Barcelona, BA in English-French)

A word is needed concerning the fact that the students who saw English as a challenge for minority languages did not explicitly mention Catalan, and more ambiguously talked about threats to 'minor languages', 'second languages', or 'the rest of languages', instead. Besides, these discourses on the defence of non-nation-state languages were not mobilised by those who had chosen to major in English and Catalan (but by those who studied English and French), as would have been expected, given the fact that many of them overtly defended pro-Catalan independence attitudes in the 
classroom. There are two main reasons that may account for this fact: the particular sociolinguistic context of the university and the geo-demographic profile of the student group under study.

Concerning the first aspect, it may be the case that students perceive that the vitality of Catalan is already secured and optimal, and therefore, they may find it problematic to state that this language is under threat because of English, at the UAB (see Garrett et al., 2012, and Llurda et al., In Press, too). After all, this was the first Catalan university to officialise Catalan as its first institutional language, after Franco's death (Pons Parera, 2015). Besides, today the Governing Council keeps defining it as 'la llengua pròpia' or the institution's own language (UAB Governing Council, 2011b), and, strategically, indirectly treats Spanish as an international lingua franca by stressing its key role for internationalisation (see Introduction).

Further evidence for the claims that the use of Catalan at university is conceived of as being normalised is provided by Ieva, a Lithuanian CLDsE Erasmus student. In her essay 'Easter European immigrant's acceptance in Catalonia' (Excerpt 15), Ieva expresses surprise about the sociolinguistic behaviours of local students, who, she perceives, tend to establish communication in and through Catalan in this particular educational discursive space, regardless of their bilingual competence in Catalan and Spanish.

15. Catalans tend to speak Catalan between themselves (and it is natural), but the strange thing is that they might continue speaking in Catalan even if a foreigner could speak Spanish. Thus, an eastern European immigrant could sometimes feel embarrassed and like fish out of water in Catalonia's society. (Ieva, female, 21, Erasmus from Lithuania, BA in English-Spanish)

I suggest that local supporters of minority languages, in fact, made explicit attempts to present Catalan as a fully-fledged European language, detaching themselves from older ethnolinguistic discourses which directly tied this language to an essentialised Catalan identity (and, by extension, to the Catalan nation-building project). They treated Catalan as a 'strong' language having the same weight (and therefore, deserving the same rights) as any other 'medium-sized' world language (Vila, 2015, p. 1). This is illustrated by Alba (Excerpt 16), who, in her essay 'Catalan is not 
endangered', explains that Catalan is a post-national language of global reach which is worth investing in.

16. Catalan is one of the most spoken languages in the world. [...] The $9^{\text {th }}$ language with more speakers in Europe, according to the UNESCO. [...] And not only Catalan society, but authorities also will not allow Catalan to disappear. (Alba, female, 21, Lleida, BA in English-Catalan)

Despite these discourses, though, the fact that none of the CLDsE students mentioned the Spanish language in their essays may reveal the difficulties that they still have when addressing the complex bilingual reality of their immediate social context. This shows that, to a certain extent, the explicit assignment of particular status quos to the two local languages is still a sensitive issue that they apparently tried to skirt (it may be the case that they were also following a 'political correctness' strategy which does not allow for the explicit criticism of any human code, out of respect for linguistic ecology; see Muehlmann, 2007).

The avoidance of emotional displays concerning what particular roles shall be granted today to both Catalan and Spanish may be linked to the particular geodemographic configuration and to the sociolinguistic dynamics of the group under analysis. As outlined in Section 2, this student cohort, except for the Erasmus students, came from four distinct regions in (or near) Catalonia: the Balearic Islands; Spanish communities where Catalan is also official and/or has traditionally played a role (València, Alacant, Aragó); Catalan-dominant villages and townships; and metropolitan cities near Barcelona. What they shared is that their individual mobility trajectories all converged in that globalised city, as the vast majority reported having left their hometowns to share a flat with other students and to enjoy an independent urban lifestyle. This occurred during a crucial turning point in their lives, university entrance in early adulthood, when individuals show a tendency to shape, model or change their sociolinguistic comportments so as to better adapt to one's new immediate community of socialisation (Pujolar \& Puigdevall, 2015). In this sense, it can be claimed that these students' linguistic trajectories had become increasingly similar. They all networked in an academic setting where Catalan predominates, and they socialised in and around Barcelona, where (1) Spanish is used extensively among this age cohort (Torrijos, 
2013); (2) where bilingual Catalan/Spanish practices seem to have been 'normalised' (i.e. de-politicised and de-ethnicised; Woolard \& Frekko, 2013); and where (3) English has colonised many spaces of the urban arena as a distinct landmark of cosmopolitanism and modernity, in the era of late capitalism.

\section{Concluding remarks}

In this paper, I have tried to contribute to a better understanding of the radical transformation that traditionally non-English-speaking bilingual university systems in Europe are currently undergoing, through a socio-economic restructuring that is turning them into market-ridden transnational ventures, following the globalisation dynamics that characterise the present-day era of "late capitalism" (Heller \& Duchêne, 2012, p. 3). By providing a deeply historicised, context-grounded exploration of the ways in which a particular unchartered pioneering Catalan university, the Autonomous University of Barcelona (UAB), designed new educational policies geared towards the attainment of its internationalisation mission, I have argued that Catalan tertiary education institutions are now immersed into the 'making' of the frequently idealised $21^{\text {st }}$-century multilingual university.

I have shown that these internationalisation projects are inextricably linked to the establishment of new language policies which, in the case of Catalonia, have propelled the institutionalisation of 'trilingualism', in part due to the pressures (and economic incentives) of the Catalan governmental authorities, now fully invested in systematising the knowledge and use of a third foreign language at university as "a firstorder strategic choice" (Mas-Colell, 2002, p. 19; author's translation). ${ }^{10}$ I have also focused on the apparently conflicting forces that Catalan universities have had to deal with when including trilingualism into their language plans, for two reasons. Firstly, because the teaching and learning of a foreign language in this region is a relatively new phenomenon, and because not all university stakeholders are ready (or are willing) to take this challenge; and, secondly, because the insertion of yet a third language into the universities' discursive spaces has had to be conducted in a very careful manner, at a time when the roles of the two co-official local languages, a majority nation-state language (Spanish) and a minority national language with a long historical trajectory of prosecution (Catalan), were, and are, object of heated debate. 
I have explained, too, that this trilingual strategy has materialised in a sort of a language intervention plan which aims at: (1) safeguarding and promoting Catalan as part of the broader Catalan nation-building process that we are witnessing in Catalonia, which started after the dictatorship, when the UAB could finally secure its role as the language of the university's community; (2) ambiguously respecting the local officiality of Spanish, too, and highlighting its global reach by constructing it as a geopolitical and economic resource for 'internationalisation'; and, finally, (3) gradually enforcing the knowledge of English (still euphemistically called a 'third language') up to a credentialed B2 level, from the academic year 2015-2016.

I have then centred on the public institutional discourses with which the UAB has legitimised this language intervention plan, and I have shown that this institution has embraced the prototypical neoliberal rhetoric which fosters 'multiculturality', 'intercultural competence', 'respect' and 'acknowledgement' of linguistic diversity. These are fashionable floating labels which index efficiency, tolerance, democracy, and civism, but which tend to be very elusively defined, for they do not actually materialise in any concrete advancement concerning the welcoming of the real heteroglossic multilingual practices that are colonising the university classrooms.

My critique of trilingualism has also revolved around the consequences that direct language intervention has had for the university's community members. Namely, I have exposed that the $\mathrm{UAB}$, by choosing to foster English as the de facto foreign European lingua franca to be included in the curriculum, is not only legitimising, but also participating in, the officialisation of the hegemonic status quo that the European Higher Educational Area has already conferred to this language (as attested in Phillipson, 2006: 13), to the detriment of a real multilingual and multicultural Europe (see, e.g., Shohamy, 2013, pp. 198, 204).

At this point, I have further analysed the most recent Englishisation processes at the UAB by presenting a unique type of partial English-Medium of Instruction major: the Combined Languages Degrees in English (CLDsE), which have had an unrivalled success in Spain. I have posited that these degrees epitomise the ways in which Catalan higher education institutions are trying to cleverly capitalise on those students who project their future employability prospects upon the mastering of the English language in a truly multilingual manner, with the credentialing of a philological profile including up to three languages, by maximising the resources of the Faculty of Letters, which was then losing out in student registration numbers. 
In the analysis section, I have approached the issue of how the Englishisation process is experienced and envisaged at university, on the ground, by putting those who decided to invest, first-hand, in its design and deployment on the spotlight: the students. I have tried to contribute to the growing body of literature on how these crucial social agents perceive the Englishisation of the Catalan higher education system by providing an informant-oriented, socially engaged, sociolinguistic analysis of an ethnographic basis, including, basically, two years of fieldwork. This has allowed me to collect observational data gathered as the CLDsE coordinator and as an instrumental English instructor as well as a set of formal argumentative essays written by $50 \%$ of all second year students who became the third promotion of students to enrol in the CLDsE.

I have displayed a series of favourable and unfavourable attitudes towards the English language, mobilised as a reaction to a controversial article which was critical about the English-only language movement in the United States, and which was accompanied by a series of discursive triggers concerning topic revolving around language in society (employment, migration, education, etc.). I have suggested that rather than either enthusiastically embracing or rejecting internationalisation processes, this student cohort seemed to simply have pragmatically accepted the idea that their work prospects may in all likelihood include the study or the work abroad experience (in fact, the vast majority of them were now spending a year in places like Dresden, Vienna, Aarhus, Frankfurt, Los Angeles, or Santa Barbara). Thus, they depicted internationalisation as something that has to be done as an investment for the future, not really as a something that may be indexical of individual freedom, personal growth and cosmopolitan lifestyle.

Likewise, they envisioned English as a neoliberal socio-economic commodity; that is, as the certified (payable and consumable) academic and professional passport with which to try to navigate the troubled globalised new economy - the unemployment rates among the Catalan youth and the increase of tuition fees at universities were the most salient topics of concern. These particular discursive tropes denoted an overprotective attitude towards their decision to invest in high-standards multilingual curriculums, for they zealously defended the idea that Englishisation would translate into the attainment of an advantaged, distinctive employability profile (hence their insistence on commanding monoglossic, 'pure' native-like English language norms).

In this sense, both internationalisation and Englishisation were conceived of as a future 'way-out' to socio-economic stagnation, surprisingly detached from their subject 
positionings and their identity projects. None of the students raised issues concerning European citizenship or mobilised a wished-for belonging to Europe, and none vindicated, either, the sort of cosmopolitan, fluid modern identities of the $21^{\text {st }}$-century (Bauman, 2005) that tend to be associated with the English language and with the central roles that it plays in the global consumerist culture, which, in early adulthood, includes music, social media gadgets and the like (Pennycook, 2007).

I have also suggested that, as prospective language experts, these students showed a high degree of reflexivity and sensitivity with regard to their own and to the other's linguistic trajectories and linguistic repertoires. They presented themselves as socially-engaged people, and they were ready to denounce linguistic marginalisation (in the United Sates as well as in discursive spaces where the rights of minority language speakers are violated). Their genuine willingness to respect linguistic diversity and to foster a balanced global ecology of languages both at home and worldwide even led them to defend a broad conception of multilingualism as inclusive of languages other than English. This may also partly explain why, perhaps as a sign of neoliberal political correctness, they surprisingly also avoided direct (re)-presentations of the self and the other in ethnolinguistic, non-post-national terms, and overwhelmingly defended their commitment to the Catalan language by avoiding the mention of its rivalling relationship with its traditional main language threat: Spanish.

Finally, I have argued that the ideological tensions that have been revealed in this paper respond to, and are a magnifying lens on, the situated positioning, the 'hereand-now', of these social actors, with regard to how they go about a restructuring of university life which now hinges upon Englishisation policies and practices. I have demonstrated that a local case study including an emic ethnographic look at the complete geo-demographic profiles and specific sociolinguistic configurations of the populations under study may provide a deep understanding of the range of nuanced stances that students display not only near cosmopolitan universities but also in Catalonia as a whole. Overall, in this particular case, a micro-level approach to what is going on in the classroom has allowed me to conclude that the new generations of Catalan university students participate in, and legitimise, the socially-stratifying "linguistic regimes" (Kroskrity, 2000, p. 3) or hegemonic language hierarchies that today govern the multilingual policies of higher education in Europe, reproducing the power structures which assign superior roles to the English language, but with some 
critical voices definitely calling for an equilibrium in the local political economies of language of late capitalism.

, apart from the fact that they show that the overarching power of English as a lingua franca worldwide is left, again, unquestioned and unproblematised,

\section{References}

Baker, C. (1992). Attitudes and Language. Clevedon: Multilingual Matters.

Bastardas, A. (2003). Les llengües a la Universitat: mobilitat estudiantil i normalització lingüística. Enxarxa't, 3, 6-9.

Bauman, Z. (2005). Identitat: Converses amb Benedetto Vecchi. València: Publicacions de la Universitat de València.

Bourdieu, P. (1977). Outline of a Theory of Practice. Cambridge: Cambridge University Press.

Bourdieu, P. (1986). The forms of capital. In J. G. Richardson (Ed.), Handbook of Theory and Research for the Sociology of Education (pp. 241-258). New York: Greenwood Press.

Cots, J. M. (2013). Introducing English-Medium Instruction at the University of Lleida, Spain: Intervention, Beliefs, and Practices. In A. Doiz, D. Lasagabaster \& J. M. Sierra (Eds.), English-Medium Instruction at Universities: Global Challenges (pp. 106-128). Bristol: Multilingual Matters.

Cots, J. M., Lasagabaster, D. \& Garrett, P. (2012). Multilingual policies and practices of universities in three bilingual regions in Europe. International Journal of the Sociology of Language, 216, 7-32.

Cots, J. M., Llurda, E., Armengol, L. \& Arnó, E. (2013). Internacionalització i gestió del multilingüisme a la Universitat. In L. Armengol, J. M. Cots, E. Llurda \& G. Mancho-Barés (Eds.), Universitats internacionals $i$ plurilingües? Entre les polítiques $i$ les pràctiques a les universitats de Catalunya (pp. 13-23). Universitat de Lleida: Edicions de la Universitat de Lleida.

Cots, J. M., Llurda, E. \& Garrett, P. (2014). Language policies and practices in the internationalization of higher education on the European margins: An introduction. Journal of Multilingual and Multicultural Development, 35(4), 311-317. 
Deem, R. (2001). Globalisation, new managerialism, academic capitalism and entrepreneurialism in universities: Is the local dimension still important? Comparative Education, 37(1), 7-20.

Del Valle, J. (2006). US Latinos, la hispanofonía, and the language ideologies of high modernity. In C. Mar-Molinero \& M. Stewart (Eds.), Globalization and Language in the Spanish-Speaking World: Macro and Micro Perspectives (pp. 27-46). Houndmills: Palgrave Macmillan.

DOGC. (2003). Llei 1/2003, de 19 de febrer, d'universitats catalanes (Report No. 3826). Retrieved February 11, 2015, from Diari Oficial de la Generalitat de Catalunya http://portaldogc.gencat.cat/utilsEADOP/PDF/3826/318788.pdf

DOGC. (2014). Llei 2/2014, de 27 de gener, sobre Acreditació dels coneixements en Llengua Estrangera. (Report No. 6551). Retrieved February 19, 2015, from Diari Oficial de la Generalitat de Catalunya http://portaldogc.gencat.cat/utilsEADOP/PDF/6551/1336006.pdf

Duchêne, A. (2011). Néolibéralisme, inégalités sociales et plurilinguisme: L'explotation des ressources langagières et des locuteurs. Langage et Société, 136, 81-106.

Duchêne, A., Moyer, M. G., \& Roberts, C. (2013). Introduction: Recasting Institutions and work in multilingual and transnational spaces. In A. Duchêne, M.G. Moyer \& C. Roberts (Eds.). Language, Migration and Social Inequalities. A Critical Sociolinguistic Perspective on Institutions and Work (pp. 1-21). Bristol: Multilingual Matters.

Estella, M. (2013). 'Per què en diem tercera llengua si volem dir anglès?' Apunts sobre multilingüisme i internacionalització a la Universitat. In L. Armengol, J. M. Cots, E. Llurda \& G. Mancho-Barés (Eds.), Universitats internacionals $i$ plurilingües? Entre les polítiques i les pràctiques a les universitats de Catalunya (pp. 45-53). Universitat de Lleida: Edicions de la Universitat de Lleida.

Eurobarometer.( 2006). Europeans and their languages. 2006. (Report No. 243). Retrieved February 11, 2015, from the European Commission, Directorate General for Education and Culture, Directorate General Press and Communication http://ec.europa.eu/public_opinion/archives/ebs/ebs_243_en.pdf

Exceltur. (2013). Estudio Impacto Económico del Turismo IMPACTUR 2013. Retrieved March 4, 2015, from Govern de les Illes Balears, Conselleria de Turisme i 
Esports http://exceltur.org/wp-content/uploads/2014/12/IMPACTUR-Baleares2013.pdf

Fairclough, N. (2006). Language and Globalization. London and New York: Routledge.

Flors, A. (2013). L'idioma que ens connecta a tots. Els discursos sobre l'aprenentatge de l'anglès dels adolescents de Mataró. Treballs de Sociolingüística Catalana, $23,205-233$.

Garrett, P., Cots, J. M., Lasagabaster, D., \& Llurda, E. (2012). Internationalisation and the place of minority languages in universities in three European bilingual contexts: A comparison of the student perspectives in the Basque Country, Catalonia and Wales. In A.Yiakoumetti (Ed.), Harnessing Linguistic Variation to Improve Education (pp. 139-166). Oxford: Peter Lang.

Garrett, P., \& Gallego Balsà, L. (2014). International universities and implications for minority languages: views from university students in Catalonia and Wales. Journal of Multilingual and Multicultural Development, 35(4), 361-375.

Geller, A. (2006, May 20). English language debate renews question. The Associated Press. May 20. Retrieved from http://www.apnewsarchive.com/2006/EnglishLanguage-Debate-Renews-Questions/id-4d60643b0fc78aed18b43f0d3b771280

Harvey, D. (2005). A Brief History of Neoliberalism. Oxford: Oxford University Press.

Heller, M. (2006 [1999]). Linguistic Minorities and Modernity: A Sociolinguistic Ethnography. London: Continuum.

Heller, M. \& Duchêne, A. (2012). Pride and profit: Changing discourses of language, capital and nation-state. In A. Duchêne \& M. Heller (Eds.), Language in Late Capitalism: Pride and Profit (pp. 1-21). New York: Routledge.

Huguet, À. (2007). Language use and language attitudes in Catalonia. In D. Lasagabaster \& À. Huguet (Eds.), Multilingualism in European Bilingual Contexts (pp. 17-39). Clevedon: Multilingual Matters.

Huguet, À. \& Lasagabaster, D. (2007). The linguistic issue in some European bilingual contexts: Some final considerations. In D. Lasagabaster \& À. Huguet (Eds.), Multilingualism in European Bilingual Contexts (pp. 234-251). Clevedon: Multilingual Matters.

Idescat. (2013a). Ensenyament universitari. Alumnes matriculats. Per sexe i universitats. $\quad$ Retrieved March 18, 2015, from http://www.idescat.cat/pub/?id=aec\&n=753 
Idescat. (2013b). Coneixement de llengües: català, castellà, anglès i francès. Retrieved February 11, from http://www.idescat.cat/dequavi/?TC=444\&V0=15\&V1=4

Idescat. (2014). Padró municipal d'habitants per sexe. Retrieved February 16, 2015, from

http://www.idescat.cat/territ/basicterr?TC $=8 \& \mathrm{~V} 3=669 \& \mathrm{~V} 4=446 \& \mathrm{ALLINFO}=$ TRUE $\& P A R E N T=1 \& V 0=3 \& V 1=0 \& C T X=B \& V N=3 \& V O K=$ Confirmar

Kirkpatrick, A. (2011). Internationalization or Englishization? Medium of Instruction in Today's Universities. Hong Kong. Centre for Governance and Citizenship Working Paper Series 2011/003. Institute of Education. Retrieved December 22 , 2014 ,

from

http://libir1.ied.edu.hk/pubdata/ir/link/pub/AK\%20CGC\%20occasional\%20pap er\%20final_final_----\%20Prof\%20\%20Kirkpatrick.pdf

Krzyzanowski, M. \& Wodak, R. (2011). Political strategies and language policies: The European Union Lisbon strategy and its implications for the EU's language and multilingualism policy. Language Policy, 10(2), 115-136.

Kroskrity, P. V. (2000). Regimes of Language. Ideologies, Polities, and Identities. Santa Fe, New Mexico: School of American Research Press and James Currey.

Lasagabaster, D., Cots, J. M., \& Mancho-Barés, G. (2013). Teaching staff’s views about the internationalisation of higher education: The case of two bilingual communities in Spain. Multilingua, 32(6), 751-778.

Llurda, E. (2009). Attitudes towards English as an international language. In F. Sharifian (Ed.), English as an International Language: Perspectives and Pedagogical Issues (pp. 119-134). Bristol: Multilingual Matters.

Llurda, E., Cots, J. M. \& Armengol, L. (2014). Views on multilingualism and internationalization in higher education: Administrative staff in the spotlight. Journal of Multilingual and Multicultural Development, 35(4), 376-391.

Llurda, E., Doiz, A. \& Sierra, J. M. (In Press). Students' representations of multilingualism and internationalisation at two bilingual universities in Spain. In A. H. Fabricius \& B. Preisler (Eds.), Transcultural Interaction and Linguistic Diversity in Higher Education: The Student Experience. Houndmills: Palgrave Macmillan.

Mas-Colell, A. (2002). Els camins europeus de Catalunya: La universitat. Col-lecció Parlaments 16. Generalitat de Catalunya. Departament d'Universitats, Recerca 
i Societat de la Informació. Barcelona: Grinver S.A. Retrieved March 17, 2015, from http://www.econ.upf.edu/ mcolell/uni res/camins u.pdf

Muehlmann, S. R. (2007). Defending Diversity: Staking Out a Common, Global Interest? In A. Duchêne \& Heller, M. (Eds.), Discourses of Endangerment (pp. 14-34). New York, NY: Continuum.

Observatori Català de la Joventut. (2015). Situació laboral de les persones joves a Catalunya. $4 t$ trimestre de 2014. Generalitat de Catalunya. Departament de Benestar Social i Família. Direcció General de Joventut. Retrieved February 22, 2015, from http://ejoventut.gencat.cat/web/.content/ejoventut/recursos/tipus de recurs/documentacio/arxiu/document/informes epa /Informe_EPA_4rt_trimestre_2014.pdf

OSU. (2013). El preu de la carrera. Preus universitaris 2013-2014 i anàlisi de l'evolució del preu total dels estudis. Barcelona: Observatori del Sistema Universitari. Barcelona. Retrieved February 26, 2015, from http://www.observatoriuniversitari.org/Fitxers/CostCarreres2013/Carrera.pdf

OPUC. (2015). Higher Education Language Policy Documents. Observatori del Plurilingüisme a les Universitats Catalanes. Universitat de Lleida. Departament d'Anglès i Lingüística. Retrieved February 10, 2015, from http://www.opuc.udl.cat/en/indicators/langpolicydocs.html

Pennycook, A. (1994). The Cultural Politics of English as an International Language. Harlow: Longman.

Pennycook, A. (1998). English and the Discourses if Colonialism. London: Routledge. Pennycook, A. (2007). Global Englishes and Transcultural Flows. London: Routledge. Phillipson, R. (1992). Linguistic Imperialism. Oxford: Oxford University Press.

Phillipson, R. (2006). English, a cuckoo in the European higher education nest of languages? European Journal of English Studies, 10(1), 13-32.

Phillipson, R. (2009). English in higher education. Panacea or pandemic? Angles on the English-Speaking World, 9, 29-57.

Piller, I. (2011). Intercultural Communication: A Critical Introduction. Edinburgh: Edinburgh University Press.

Pons Parera, E. (2015). The position of Catalan in higher education in Catalonia. In F. X. Vila \& V. Bretxa (Eds.), Language Policy in Higher Education The Case of Medium-Sized Languages (pp. 153-180). Bristol: Multilingual Matters. 
Pujolar, J. (2001). Gender, Heteroglossia and Power: A Sociolinguistic Study of Youth Culture. Berlin: Mouton de Gruyter.

Pujolar, J. \& Puigdevall, M. (2015). Linguistic mudes: How to become a new speaker in Catalonia. International Journal of the Sociology of Language, 231,167-187.

Rosselló i Peralta, C. de \& Boix-Fuster, E. (2003). Les ideologies lingüístiques de l'alumnat de la UB. Enxarxa't, 3, 4-5.

Rosselló i Peralta, C. de \& Boix-Fuster, E. (2006). An unbalanced trilingualism: Linguistic ideologies at the University of Barcelona. Catalan Review, 20, 153171.

Sabaté i Dalmau, M. (2014). Migrant Communication Enterprises: Regimentation and Resistance. Bristol: Multilingual Matters.

Sastre Bestard, B. (2013). Opinions i pràctiques lingüístiques dels alemanys residents a Mallorca. In F. X. Vila \& E. Salvat (Eds.), Noves Immigracions i Llengües. (pp. 227-250) Barcelona: MRR.

Shohamy, E. (2013). A critical perspective on the use of English as a Medium of Instruction at universities. In A. Doiz, D. Lasagabaster \& J. M. Sierra (Eds.), English-Medium Instruction at Universities: Global Challenges (pp. 196-210). Bristol: Multilingual Matters.

SIR WR SCImago. (2014). Scimago Institution Rankings World Report 2014. Retrieved December 22, 2014, from http://www.scimagoir.com/institution.php?idp=35800

Torrijos, A. (2013, December 11-12). Les trajectòries lingüístiques de les persones joves a Catalunya. II Jornades 'La recerca sociolingüística en l'àmbit de la llengua catalana'. Xarxa Cruscat, Institut d'Estudis Catalans, Barcelona.

UAB Àrea de Comunicació i Promoció. (2012). Els Graus Combinats de Llengües. Internal report. Bellaterra: Universitat Autònoma de Barcelona.

UAB Àrea de Comunicació i Promoció. (2014). A welcome in any language. Retrieved December 22, 2014, from http://www.uab.cat/web/videos/reproduccio1192707516892.html?param1=30CampusUAB \&param2=05promocio\&param 4=Llengues\&param5=1\&url video=1345671833224

UAB Àrea de Comunicació i Promoció. (2015a). La UAB en xifres. Retrieved February 9, 2015, from http://www.uab.cat/web/coneix-la-uab-cei/la-uab-en-xifres$\underline{1345668117455 . \mathrm{html}}$ 
UAB Àrea de Comunicació i Promoció. (2015b). All Bachelor's Degrees. Retrieved January, $\quad 3, \quad 2015, \quad$ from $\quad$ http://www.uab.cat/web/studyabroad/undergraduate/undergraduate-offer/all-bachelor-s-degrees1345667078809.html

UAB Àrea de Comunicació i Promoció. (2015c). El Grau en xifres. Retrieved 3 January, 2015, from http://www.uab.cat/web/estudiar/llistat-degraus/informacio-general/x-1216708251447.html?param1=1265095343849 (English-Catalan), http://www.uab.cat/web/estudiar/llistat-de-graus/el-grau-enxifres/estudis-d-angles-i-espanyol-

1297754209672.html?param1=1265181666042 (English-Spanish), http://www.uab.cat/web/estudiar/llistat-de-graus/el-grau-en-xifres/x1297754209672.html?param1=1265181666809 (English-Classics), http://www.uab.cat/web/estudiar/llistat-de-graus/el-grau-en-xifres/estudis-dangles-i-frances-1297754209672.html?param1=1264578113763 $\quad$ (EnglishFrench).

UAB Governing Council. (2011a). Plan for Languages 2011-2015. Retrieved December 22 , 2014 , from http://www.uab.cat/Document/737/609/CampusPlaLlengues20112015_en.pdf

UAB Governing Council. (2011b). Pla de Llengües 2011-2015. Retrieved January 3, 205 , from http://www.uab.cat/Document/22/553/CampusPlaLlengues20112015 ca,0.pdf

Vila, F. X. (2015). Language policy in higher education in medium-sized language communities: An introduction. In F. X. Vila \& V. Bretxa (Eds.), Language Policy in Higher Education The Case of Medium-Sized Languages (pp. 1-14). Bristol: Multilingual Matters.

Wee, L. (2008). Linguistic instrumentalism in Singapore. In P. K. W. Tan \& R. Rubdy (Eds.), Language as Commodity: Global Structures, Local Marketplaces (pp. 31-43). London: Continuum.

Woolard, K. A. \& Frekko, S. A. (2013). Catalan in the twenty-first century: Romantic publics and cosmopolitan communities. International Journal of Bilingual Education and Bilingualism, 16(2), 129-137. 


\section{Appendix}

[Insert Table 1 here]

[Insert Table 2 here] 


\section{Notes}

${ }^{1}$ This study was funded by two research grants awarded by the Catalan Department of Economy and Knowledge and by the Spanish Ministry of Economy and Competitiveness. The former was granted to X at the University of $X$ (reference $X$ ), and the latter to the research group $X$ at the University of $X$ (reference X). I am very thankful to the UAB academic and administrative staff at the Faculty of Letters for their help with this project, as well as to the Catalan university students of Combined Languages Degrees in English for their kind participation in this study. I also benefited from X's insightful comments on earlier versions of this paper. Any shortcomings are, of course, mine.

2 These are (in alphabetical order): Universitat Autònoma de Barcelona, Universitat de Barcelona, Universitat de Girona, Universitat de Lleida, Universitat Politècnica de Catalunya, Universitat Pompeu Fabra, Universitat Rovira i Virgili and Universitat Oberta de Catalunya (the last one has a semi-private, mixed nature, though it belongs to a public Foundation, the FUOC, regulated by the Catalan Administration).

${ }^{3}$ Note that, today, all Catalan students are fully-fledged bilinguals with a proficient command of both Catalan and Spanish after their post-obligatory secondary education (Huguet, 2007: 34).

${ }^{4}$ Apart from English, the UAB Plan for Languages also lists French, German, Italian and Chinese and Korean as playing "an important role" for geostrategic and economic reasons (UAB Governing Council, 2011a).

${ }^{5}$ At the time of writing, apart from the Combined Languages Degrees in English, three official majors offered the EMI option: Business Management and Administration, Economics, and Primary Education. Besides, $25 \%$ of the UAB MA programs were offered in English, too (UAB Àrea de Comunicació i Promoció, 2015b).

${ }^{6}$ In 2014, the English Studies degree had registered 324 first- to fourth-year students; French Studies, 46; Spanish Studies, 151; Classics 75; and Catalan, 68.

${ }^{7}$ During the first four years of their implementation, all CLDsE had to undergo some readjustment to better suit the students' needs. For instance, the CLDsE Student Delegation had to be created anew; schedules had to be modified for students to be able to access the Minors in their third foreign language; and requirements to register to particular higher CEFR-level courses had to be clarified in order to avoid re-sittings as much as possible. This is the reason why meetings with students (as well as with the Academic Affairs Committee and with the Faculty Board) were held on a regular basis.

${ }^{8}$ Original quote: "En primer año de inglés [los professores] nos machacan con Usos bàsics como tendría que ser con todas las demás asignaturas."

${ }^{9}$ Note that the latest language policy which will require all Catalan university students to have achieved a B2.2 level of English by the end of their degrees from the academic year 2015-2016 (see DOGC, 2014, p. 162) had not been passed at the time of the fieldwork.

${ }^{10}$ Original quote: "una opció estratègica de primer ordre." 


\section{Tables:}

Table 1. Number of new students enrolled in the four Combined Languages Degrees in English, per year

\begin{tabular}{|l|l|l|l|l|l|l|l|l|}
\hline Degree: & \multicolumn{2}{|l|}{ English-Catalan } & \multicolumn{2}{|l|}{ English-Spanish } & \multicolumn{2}{|l|}{ English-Classics } & \multicolumn{2}{l|}{ English-French } \\
\hline Registration No. & Total & New & Total & New & Total & New & Total & New \\
\hline 2009 & 9 & 9 & 26 & 26 & 5 & 5 & Not offered \\
\hline 2010 & 38 & +33 & 48 & +34 & 21 & +17 & 30 & +30 \\
\hline 2011 & 52 & +30 & 68 & +34 & 34 & +27 & 54 & +35 \\
\hline 2012 & 64 & +29 & 87 & +32 & 48 & +32 & 71 & +32 \\
\hline 2013 & 75 & +30 & 100 & +37 & 47 & +21 & 95 & +34 \\
\hline 2014 & 76 & +29 & 112 & +35 & 36 & +14 & 103 & +33 \\
\hline
\end{tabular}

Source: UAB Àrea de Comunicació i Promoció (2015c).

Table 2. CLDsE students' gender and age, per degree (2014)

\begin{tabular}{|l|l|c|}
\cline { 2 - 3 } \multicolumn{1}{c|}{} & Gender (2014) & Mean age (2014) \\
\hline English-Catalan & $79 \%$ women & 19 \\
\hline English-Spanish & $80 \%$ women & 19 \\
\hline English-Classics & $43 \%$ women & 19 \\
\hline English-French & $82 \%$ women & 19 \\
\hline
\end{tabular}

Source: UAB Àrea de Comunicació i Promoció (2015c). 